\title{
Filipina Maids In Malaysia In the 20th Century
}

by

\section{Chin Yoon Fong}

The year 1995 has been a momentous though ominous one in the history of Filipina maids in Southeast and West Asia. In the former. Flor Contemplacion was sentenced to death by the Singapore courts for killing her employer's young son while in the United Arab Emirates, Sarah Balagan had her death sentence commuted to a hundred strokes of the rattan and a one year gaol sentence by the Court of Appeal there for battering her old employer to death after he had allegedly molested and raped her on a few occasions. These two incidents over the ill- or maltreatment of Filipina maids are neither rare nor isolated; they have received world-wide publicity and mass hysteria has resulted only because lives have been lost in the process thereby leading to recriminatory measures by injured or affected parties with eventual intervention by the Filipino government for clemency for the maids concerned.

The entry of Filipina maids on the economic scene on a worldwide scale stretching from Canada and Europe in the Western hemisphere to Kuwait, Saudi Arabia, Hong Kong and Singapore in the Middle and Far East is a recent 20 th century phenomenon but already the maids' presence has caused more than a ripple in these countries. In Malaysia the mass employment of Filipina maids in Malaysian homes especially in urban areas like Kuala Lumpur and Ipoh since the 1980's has tended to change the work pattern considerably even though such labour is generally of a transient kind. It is the purpose of this essay to trace the movement of these maids into the country and to show how their presence here has affected the soclo - economic fabric of Malaysia in recent times. 


\section{JURNAL SEWARAH}

BACKGROUND TO FILIPINA have been subordinated to the men, Filipinas have en high status ever since the advent of che love and the inspiration the late 16th century. Lauded allowed to mix freely with the men, to take the home', the women "were not to engage in sports and other professions. ${ }^{11}$ Because they part in politics, or to follow the rigid rules of decorum, it can be discerned that women of Spanish times were treated as cloistered and delicate creatures who went about their dainty tasks in the home while the menfolk were the actual breadwinners working in the fields or in the factories. This scenario prevailed for over three centuries until the American Occupation of the Philippines at the beginning of the 20th century.

Besides enhancing material prosperity through a greater increase in agricultural and industrial production, American rule brought about a more democratic way of life when strict social barriers crumbled and religious freedom was enhanced through inroads made by Protestantism leading thereby to the partial dislodgement of Catholicism. For the Filipinas, American rule unshackled them from their social backwardness by taking them out of the confines of the home and exposing them to the outside 'world' with their new-found freedom. Emancipation meant that they could "go out and associate with the men, to enter co-educational schools and universities, and to attend social parties even without chaperons. They were allowed to work in factories and offices, to engage in business, to attend political meetings, and to participate actively in sports". ${ }^{2}$ The right to vote, granted to women in 1937 after a tedious and prolonged campaign in Parliament led by commonwealth President Quezon and other suffragettes, marked the final victory for Filipinas in their fight for equality with men.

Despite economic progress experienced under American rule after the collapse of the First Philippine Republic, renowned leaders like Quezon. harboured dreams of attaining independence from colonial domination. This they managed to achieve only in 1946 after the second World War. The economic setbacks in the national economy caused by the War and the postwar departure of the Americans served to make the Filipinos more resilient when they had to put their own house in order thereafter. Subsequently. economic recovery enabled the national income derived from agriculture. industrial production and other sources to gross P.10.3 billion one decade later. Contributions from the most significant sector of the economy, namely. cobacco, sugar, abaca and coffet production. ${ }^{3}$ The establishment of industries in the 1950 s saw the openint of car-assembly plants, aluminium, battery and wire factories, textile mills 
and cigarette plants. Both the agricultural and industrial sectors in the country provided jobs and absorbed large numbers of the population apart from their contribution to the national coffers. ${ }^{4}$

The euphoria of self government and the enthusiasm to become economically self-sufficient encouraged the Filipino government to embark on a series of national programmes spread out over four or five year periods in order to organise its economic development. This was especially evident during the Marcos era when President Ferdinand Marcos governed the country with an iron hand by declaring martial law in 1972. For instance, the Five Year Plan of 1978 -82 was directed towards lowering disparity in income, creating greater employment opportunities, reducing price fluctuations and opening new sources of energy supply such as oil and nuclear power plants. Most significantly, its primary goal was to strive for self-sufficiency in the agricultural sector. ${ }^{5}$ In its eagerness to achieve economic goals within a short time span, the Philippine government resorted to huge borrowing of foreign funds to finance its large imports of capital goods such as machinery and heavy equipment. This meant that an appreciable increase in the amount of exported goods comprising essentially sugar, copper, textile products and cement during this period failed to set-off the much higher volume of imports. Consequently, the foreign debt, which stood at US\$2.2 billion in 1972 . escalated to US\$5.5 billion in 1976 and US\$6.57 billion one year later. ${ }^{6}$ The debt service ratio, i.e. the ratio between debt service payment and export earnings, exceeded $30 \%$ by the end of that decade when it rose to US\$963 million in 1978 which was more than the US\$950 million limit imposed on foreign loans by the International Monetary Fund (IMF). ${ }^{7}$

On the domestic scene, running inflation and the correspondingly weak purchasing power of the peso coupled with the rising cost in living standards created hardship and unrest among the population both in the rural and urban areas. Even a hike in the minimum wage, viz. from P.11 to P.12 per diem and from P. 10 to P.11 per diem for non-agricultural workers in the Metro and non-Metro Manila regions respectively as decreed by President Marcos in 1978 could not compensate the loss of purchasing power of the ordinary Flipino. The agricultural labourer was equally affected financially despite a raise of P.7 to P.8 per diem in the statutory minimum wage with the result that the living standard of farmers and their families was reduced to subsistence level. ${ }^{8}$

The escalation of crude oll prices in the Middle East and the threat of world recession in the late 1970 s exacerbated the worsening economic situation of the Philippines. To forestall the onslaught of recession within its shores, the Marcos government embarked on a series of stringent economic measures meant to curb exorbitant spending including reducing 
all-round government expenditure by $5 \%$ and shelving a number of $\mathrm{maj}_{\mathrm{a}}$ development projects. Unfortunaty crept in causing large-scale unemplote in the day as recession had already crept in causing large-scale unemt and economic distress among the Filipinos. The situation took a turn for the worse in the 1980s. It was reported that there was a native Gross Domestic Rate (GDP) growth rate of $4 \%$ in 1984 " reflected in production cut-backs, employment lay-offs, business failures and so on ${ }^{\text {m9. }}$. The debt service ratio, registered at $19 \%$ in 1980 , shot up to $50 \%$ three years later. As a result, the Philippines ranked top among other Asean countries in having a balance of payment deficit of US\$2.5 billion in 1983. To lower this massive deficit, it was forced to devalue the peso twice, namely, in June and October 1983 which thus saw the deficit considerably scaled down to US\$70 million by the middle of $1984 . .^{10}$ Unfortunately, the currency devaluation had an adverse impact on domestic pricing when the consumer price index (CPI) rose from $39.3 \%$ in 1983 to $45.5 \%$ a year later. ${ }^{11}$ It would appear that the plight of the Filipinos had plunged to the doldrums and only an economic miracle could offer them some semblance of a decent livelihood.

\section{FILIPINA WORKERS TO THE FOREFRONT}

Against this bleak scenario, Filipina workers were to play a dominant role in rescuing their fellowmen from the economic malaise that had befallen their country during these hard times. Rather than be house-bound, the women had become major supporters of the family especially in the countryside ever since their emancipation under American rule. When recession occurred and domestic productivity was at its ebb in the 1970s, large numbers of unemployed Filipino males in addition to Thais, Koreans, Indians, Bangladeshis, Pakistanis and Sri Lankans were fortunate enough to be absorbed into the workforce of the crude oil industry and affiliated construction projects in the Middle East which were desperately short of labour. ${ }^{12}$ Shortly after, following the footsteps of their male counterparts, Filipinas were also employed as maids in the homes of 'noveau' rich Arabs who had been able to amass their fortunes from the ofl boom that occurred during the 1970s. Despite plummetting oil prices the following decade, female migration from the Philippines to Middle East countries such as Saudia Arabia and Kuwait did not abate. Besides working in households. Fllipinas were employed as entertainers, nurses and prostitutes although the majority of migrants went overseas as househelp. As malds. they were employed

" whether their services are really needed or not. This is tantamount to a "demonstration effect" where a family's status is measured by the number of household servants/assistants it employs. This new style of social behavlour is unlikely to disappear in the short run." ${ }^{-13}$ 
However, declining oil prices at the beginning of the 1980 s after the ArabIsraeli War and the consequent lower demand for housemaids due to more restrained spending on the part of the Arab Sheikhs and their households in the Middle East encouraged intending Filipina migrant maids to turn their attention elsewhere, namely to the far-flung regions of the United States, Canada and Western Europe and the nearby areas of Hong Kong. Singapore and Malaysia for a suitable job alternative. Accustomed to earning wages overseas to support parents and siblings and unable to obtain employment in their homeland, Filipinas migrated on a large scale to these countries in the 1980 s.

Although they constituted a well-organised and sizeable workforce numbering about 20,000 in Singapore households in the mid-80s, the same could not be said about the presence of Filipina maids in Malaysia during that time. Only a handful, viz. about 200 domestic maids were found in Kuala Lumpur in 1985; these women had probably slipped into the Federal capital illegally through Singapore earlier on for they were soon deported on grounds that their visas and work permits were forged. ${ }^{14}$ It was only a year later that Filipinas were able to come to Malaysia with the blessing of the Malaysian authorities.

\section{DOMESTIC MAIDS IN MALAYSIA}

The arrival of Fllipino maids in the country in the 1980 s coincided with the urgent need of Malaysian families for domestic help during this period. The transformation of Malaysia from an economy based on commodity exportorientation of rubber and tin to one where the capitalist mode of production dependent on industrial manufacturing in the 1970s prevailed presented abundant employment opportunities for female workers and consequently encouraged a large sector of Malaysian women who had previously remained at home to enter the industrial workforce for the first time.

"Push" factors which led to such a situation included cash-income inducements among the lower classes, the need of the landless poor among the non-Malays to overcome impoverishment by offering their labour services and also the satisfaction semi-trained or trained women derived from honing their manual or educational skills in factory and office work respectively. However, comparatively speaking, it would seem that the "pull" factors during the period of industrialisation were more significant in drawing Malaysian women into the labour market. With foreign participation and the introduction of new or improved manufactured goods such as chemical products, fine woven garments and micro-electronic software. factories required deft and nimble hands. This invariably meant that female labour was encouraged since these jobs suited the propensity of women to partici- 
pate in such trades. Moreover. the peculiar nature of the work involved in say. food processing or sewe in pre-industralisation days and hence did not of work carried out nh further skills by temale labourers to get the job done. need the acquisition of Finally. gender discrining for the performance of similar jobs persuaded their male counterparts for the pertoren in their workforce. ${ }^{15}$

As a result. industrialisation and greater exposure to education since the 1970 s paved the way for Malaysian women. who would otherwise have stayed at home, to enter the booming job market as workers along the production line or clerks and secretaries in companies and corporations. To many young girls, especially those from the rural areas who would normally have shifted to the towns to become domestic maids had an upward surge in the national economy not materialized, it was preferable. from their point of view, to receive low wages and maintain their independence than to be tied to mundane domestic chores and have their freedom fettered. ${ }^{16}$ The trend to work outside the home also affected many literate housewives so much so that it was a common phenomenon to have both the husband and wife working during those times.

It can be recalled that in the early part of this century, many Malaysian housewives, particularly those of Chinese origin, could rely on the services of loyal Chinese immigrant amah who were often willing to work a whole lifetime for their employers as soon as they had set foot in this country. Unfortunately, the heyday of reliable amah labour had gone by the 1960s. For apart from having the source of Chinese labour cut off by stringent legal controls, the majority of amah had either died of old age, returned to China for good, or had retired to their cubicles, fong, or vegetarian houses, chaitang. to spend their twilight years with their adopted "sisters" or female companions. ${ }^{17}$

Consequently, many Malaysian housewives had to source locally for domestic help, especially for girls from the rural towns and villages. However, with the migratory shift of labour from the home to the factory in the late 1970s which tended to escalate further a decade later, the supply of local househelp had virtually dried up. The end result was a dire shortage of domestic maids to cook, clean the house and babysit young children in many Malaysian homes.

The arrival of the Filipinas in Malaysia in the 1980s was a godsend to many desperate households as they managed to fill a vacuum created by the departure or absence of local domestic malds who had preferred a "careerchange" in the industrial sector. It has already been noted that hardly a year 
elapsed after the repatriation of "illegal" Filipina maids in 1985 that the Malaysian government. in an unprecedented move to ease the shortage of domestic labour. decided to legalise the entry of new Filipina migrants as long as they adhered to proper immigration procedures. ${ }^{18}$ The relaxation of rules governing foreign, 1.e. Filipino immigration, opened the floodgates to Filipino maids, who with the full endorsement and assistance of the employment agencies, both locally and in the Philippines, started the migration process by entering the country in droves in order to seek employment in Malaysian homes.

\section{THE ROLE OF EMPLOYMENT AGENCIES}

It should be mentioned that although there were three modes of maid recruitment in the Philippines, namely, through government auspices via the Government Placement Department (GPD) of the Philippine Overseas Employment Agency (POEA), through direct hiring on a private basis and through recruitment by private employment agencies, the last was the most common and usual mode used for bringing in Filipina maids to Malaysia. ${ }^{19}$ In the first method, recruitment through POEA was more applicable in the case of contract workers who were mostly semi-skilled, skilled and/or professional persons such as construction labourers, nurses, doctors and entertainers. Hiring on a private and direct basis occurred when workers managed to secure employment on their own without going through a third party such as the employment agency although their work and leave documents had to be processed by the GPD of POEA. However, Filipina maids who were deployed this way were generally at risk since they could not turn to any agency for assistance in times of financial or emotional distress though they could have recourse to their own embassy as a last resort. On the employers' side, cases abound where many Malaysian employers who had obtained Filipina househelp on a private basis found that they were shortchanged when their maids absconded either to work for some other household or had changed jobs to become entertainers, bar hostesses or prostitutes.

Discussion of the recruitment process in this paper will be confined primarily to private employment agencies since the majority of Filipina maids who served in Malaysian households had been recruited largely through the efforts of agents from these centres. In Malaysia, such agencies referred to as "purely manpower suppliers.....recruiting for a principal for overseas jobs and authorised to collect a placement fee of $P .5000$ or US $\$ 250^{-20}$ and initially granted licences by the Ministry of Home Affairs in 1986, were registered as sole businesses, partnerships or corporations. Their role was essentially one of intermediary and faclitator for the supply of maids to Malaysian house- 
holds. It would appear that each agency in Malaysia had Its own pool of migrant maids despatched from its Filipino counterpart.

The procedure for sourcing maids was a tedious one for the employment agencies in the Philippines. However, obtaining contract workers for Malaysia was not a new phenomenon for the Filipino agents as they had been providing similar services to other clientele in West Asia, Hong Kong and Singapore long before the Kuala Lumpur-Manila connection commenced. Upon receiving requests for housemaids from its Malaysian partner, the Manila agency would proceed to make the necessary advertisements by calling for applications through newspapers, radio and television. In rural provinces and remote barrio or villages, pamphlets pasted on the post office and town centre billboards as well as information passed through word of mouth' by local recruiters hired by the Manila agents apparently had more effect in coaxing interested village girls to appear for job interviews.

The criterla for Filipinas to migrate overseas are many and varied. The assurance of a better life ahead with the acquisition of much higher wages ${ }^{21}$ and the attainment of a more sophisticated lifestyle in a foreign country was a prime factor in luring Filipinas overseas. For "as migrants, they gained status with their peers in the Philippines" ${ }^{22}$. On the other hand, migration was regarded as a form of escapism for women who wanted to leave abusive or uncaring spouses or divorcees who wished to start life anew elsewhere. ${ }^{23}$ Yet there were others who looked upon an overseas stint as a financially prudent move so as to amass savings to support their families or to purchase property or form small businesses after their return from their temporary sojourn overseas. Thus motivated, the town or country Filipina was eager to make a financial deposit with her agent to ensure a job placement as soon as the opportunity presented itself. This deposit came either from her own pocket or from a loan advanced by the agency which would be added on eventually to the P15,000 which she had to reimburse the agent once she succeeded in getting a job. Repayment of the loan was to be made through monthly deductions of her wages from her Malaysian employer. ${ }^{24}$

In the process of screening applicants, employment agencies required Filipinas to submit a whole list of documents including their medical certificates, "bio-data, reference letters, marriage certificates, pictures and certificate of employment for manpower pooling and screening purposes. ${ }^{24}$ More fastidious agencies would insist on further documentation to be fumished such as "(college) diploma, bank account, residence certificate baptismal certificate, tax account, voter's identification card and husband's (or father's) written consent." 28 Thereafter, interviews of applicants woulc be held by the agents or their representatives at the Manila office or othe: 
local centres in the provinces such as Pangasinan and Mindanas. for example As soon as the selection process of an applicant was completed. her file containing all personal particulars including her photographs. bio. data and medical record. torether with files of other selected applicants. were transmitted from Manila to the Malaysian office. It was then up to the local agent in Kuala Lumpur. based on the choice of the prospective employer. to decide on whether to hire the maid or not. Once an applicant was successful in getting the overseas posting, the agency took care of all other processing papers needed to finalise arrangements for the departure of the maid to Malaysia including her passport, airfare and Pre-Departure Orientation Seminar (PDOS) certificates. ${ }^{27}$

In Kuala Lumpur and Petaling Jaya where the first employment agencies were based in Malaysia. the operating costs of 'setting up shop' were minimal. All that was required was a one-room office staffed by a clerk/typist and an office boy. Very often and likely so, the proprietor would be away in Manila negotiating 'deals' with his Filipino partner over matters like the type and number of maids to be sent to Malaysla within a certain period, the amount to be paid as agency fees and transportation charges, the period of training required for the housemalds before going overseas and so on. Meanwhile, the clerk who often doubled up as office administrator unless the proprietor had a business partner (who could also be a sleeping partner), would have to process applications for Filipino maids from her end in the Kuala Lumpur office. ${ }^{28}$

For the prospective employer, the selection process for hiring a Filipino maid would entail detalled browsing of the personal file of the applicant and recommendation by the agent. It would not be too far fetched to say that despite glowing references and high recommendation, a maid was chosen purely for her 'photogenic' or pleasant looks in many instances. Once a choice was made and an advance payment, initially pegged at M\$1,500 in the 1980 s. was given for the airfare, processing fees and other miscellaneous charges. the prospective employer would be expected to wait several months before the maid's arrival. However, without properly regulated procedure over the method of recruitment in the early stages of Flipina migration into this country, recruitment tended to be haphazardly conducted. There were cases where maids, who were already in the country either because they were 'refects' or had come to Malaysia from Singapore or Thatland as tourists earlier on but had subsequently decided to register with the agency concerned, could be hired on the spot by less fussy employers. When adminstration of foreign labour became more streamlined under the Ministry of Labour later on. employers were made to pay a security fee of M\$1000 to make them accountable for the behaviour of their maids. This meant that 
abscondment, disappearance or arrest of a foreign maid found to be working or moonlighting as a social escort or involved in other unhealthy activities could result in forfeiture of the employer's security sum unless valid reasons could be given by the employer for such abscondment or misbehaviour. ${ }^{29}$

The contract maid was not only expected to be a person of integrity and good character but also the epitome of cleaniness and domestic efficiency. Indeed, the Malaysian "ma'am" had high expectations of her Filipino maid which was reminiscent of the qualities demanded of the Chinese amah of colonial days. It can be surmised that the latter could, more often than not, live up to the expectations of her employer because of similar ethnic and cultural though different socio-economic origins. Hence, she could accommodate more easily to the domestic habits of her "Towkay" (since the majority of employers in Malaysia were of Chinese descent). ${ }^{30}$

The same could not be said of the relationship of the Filipino maid visa-vis her Malaysian employer. Coming from an ethnically different background that included vast differences in the social and cultural milieu, the Filipina had major adjustments to make on her arrival in Malaysia. Even though she was taught the rudiments of elementary housekeeping including ironing, operating a washing machine and using an electric ricecooker by the agency during her training and orientation stints in the Philippines and Malaysia respectively, the Filipina maid did not always meet the requirements set by her ma'am. The fault could not be said to lie entirely with the Malaysian employer who had been 'led/misled' to expect high standards of service from her prospective maid after checking the latter's biodata/ questionaire on her application for a maid. It was not uncommon for each and every Filipina to answer all questions regarding her domestic proficiency in the affirmative in the questionaire. Although such questions were thorough and varied, ranging from her competence to cook for large families and handle electric gadgets to her ability to withstand loneliness and nostalgia in a foreign land, her answers were always a categorical "yes". ${ }^{31}$ From her biodata, the applicant gave her prospective employer the impression that no mountain was too high to climb nor river too deep to cross!

\section{THE MALAYSIAN EXPERIENCE:}

Hired at a salary of M\$300 per month in the mid-80s for an initial period of two years, (with the standard wage scheme periodically revised upwards according to regulations imposed by the Filipino government untl it reached the level of RM580 per month a decade later). ${ }^{32}$ the Fllipina housemaid, whose average age was between 20 to 45 and normally unmarried. was expected to be a "one-leg kick" like her amah predecessor in the Malaysian home. At the outset, it should be mentioned that numerous variables have to be 
contended with in discussing the different work experiences of Filipina maids. This was because the workload of a domestic servant differed in every household depending on the number of family members and according to different ways or preferences of carrying out chores, different cultural and ethnic practices and also the expectations of work performance of maids by local employers. Nevertheless, it can be said that by and large, a maid's duties were multifarious. These included washing, general cleaning of the house, baby-minding, cooking or at the least, preparation of food for the ma'am to cook, washing of cars and "any other work as instructed by the employer from time to time", ${ }^{33}$ as outlined in the employment contract..

Drawn into completely new and strange surroundings, the Filipina maid, who was normally a first-time migrant to Malaysia, ${ }^{34}$ was absorbed into the Malaysian home for such length of time until she had completed her service contract. For her, the difficulties of adjusting to her new environment could be forbidding. Not knowing what to expect of her new employer as she was normally sent from the agency direct to the household which had originally selected her, the Filipina could be despatched to the home of a rich miner in Ipoh or to a working-class couple in Malacca whose eligibility to act as employers was dependent on their financial capacity to satisfy the statutory income level required by the government. From the viewpoint of the maid. getting a kind and understanding employer or one who was a slavedriver depended on her own good fortune. Similarly, the employer could be considered to have no "luck of the draw" if she had chosen a dishonest and shoddy househelp notwithstanding the impressive biodata she had seen on the agent's desk when she first went 'maid - hunting'.

While it can be said that most poverty-stricken maids with some element of domesticity back home in the Philippines would encounter little difficulty in coping with similar chores in Malaysian households, except for minor adjustments such as those involving the use of electric appliances like the floor-hoover and the micro-oven for example, it was more the dramatic change of a foreign and unfamiliar lifestyle that encumbered many of them. Adapting to different social habits invariably meant not only getting accustomed to the ma'am's family but also following its dietary habits. The frequent consumption of noodles or bread for lunch instead of rice (which constitutes the staple diet of the majority of Filipinos three times a day) was a common instance of such a dietary change. ${ }^{35}$

For the Fulipina maids who were academically qualified, such as exteachers, secretaries or graduates, the humdrum dally routine of having to rise at dawn and plod on with their chores the whole day until late into the evening with minimal breaks in-between, was not only physically taxing but dementing too. They also begrudged employers who took advantage of their 
"qualified" status by coaxing them to tutor their young children in the little 'spare' time they had without any form of remuneration for their extra effort and not adhering to the standard terms of their service contract. Employers who tended to overload their househelp with extra domestic chores either because they had large or extended families or those who deviated from the terms of their service agreement by making their maids work in restaurants or coffee-shops instead of in the residential home ${ }^{36}$ also earned the ire and contempt of their maids.

Despite their grouses which they could air only to their agents or working colleagues in the agency house on their "off-days" which were usually Sundays for the highly religious Catholic Filipinas, the maids often suffered in silence as there was little recourse for them to rectify their complaints. Unlike her employer who could insist on and eventually succeed in terminating her contract or exchanging her househelp for another from the employment agency should her original choice turn out unsatisfactory because of fraud, pilfering, gross laziness or engagement in immoral activities on her off-days on the part of the maid, the Filipina did not have such an option but had to work for her ma'am until her term of service expired. Only in extreme cases where physical abuse was involved viz. physical violence, rape, bodily injuries or chronic and severe illness was the maid permitted to end her contract provided evidence was adduced to prove her case. Otherwise, in the event of forced repatriation due to the premature or early termination of her contract because her services were not "up to standard" and therefore were no longer required, the maid had to pay her own fare home. To ensure that her househelp had the necessary funds for this purpose, the employer, apart from paying commission and administrative charges, was required to leave a deposit of RM600 with the agency for the purchase of the maid's airfare for such an exigency. This deposit could be recovered from monthly deductions of RM100 from the maid's wages until the full sum had been reimbursed. ${ }^{37}$ The threat of repatriation and the shame and financial loss associated with such action prevented many maids from reporting the misdeeds of their employers to the relevant bodies, namely, the Philippine Embassy or the police unless they were forced to do so in extreme cases of rape or severe physical injury.

Tales of woe about cruel or hard-hearted ma'am narrated by Filipina maids to Philippine Embassy officials, counsellors of the Befrienders or the Filipina Christian groups ${ }^{36}$ belie the fact that many Malaysian employers were also not too happy with the behaviour and demeanour of their foreign househelp many a time. 
Whilst sympathising with their maids' loneliness and depression which often occurred because of separation from loved ones, be they parents, spouses or children or because of money problems brought on by incessant demands for remittances from their families, employers were nevertheless chary of the "101 reasons" given by their househelp for their disobedience. lack of discipline or intransigence. Except for some difficult taskmasters who could never be contented unless their hired help were worked to the hilt or until their homes were 'spic and span', employers in general were willing to overlook their maids' shortcomings such as their inability to cook Chinese or Malay cuisine or to speak the local Chinese dialects or Bahasa Malaysia since they were conversant only in English. So long as the maids were diligent and eager to learn the finer points of household chores, employers were generally tolerant of the former's inadequacies. But they despised dishonest maids who lied, pilfered on absconded with their belongings.

It would appear that 'bad' habits were acquired by new maids from their more experienced or "senior" counterparts. Indeed, peer pressure tended to play a dominant role in changing the behaviour and outlook of Flipina maids in this country. Docile and obedient on their initial arrival in Malaysia, many new Filipinas soon learned the "tricks of the trade" from veteran or "senior" maids who had stayed in the country for a longer stretch of time. The meeting-point for fresh recruits and "senior" maids was often the church, esentially the Catholic church which would be the hub of activity for maids on their "off-days" on Sundays. Besides attending Mass and other religious activities such as prayer meetings and choir singing, many Filipinas would indulge in gossip sessions after service where information on their employers and their families back home in the Philippines would be heatedly exchanged. Jumble sales were also periodically held in the church grounds in which cookjes, clothes, houseware and jewellery would be bartered among the Fllipinas and their friends.

Apart from the church, the agency house ${ }^{39}$ where malds could go to relax and spend the day as well as shopping malls ${ }^{40}$ in the city also served as 'social' centres for the maids to interact with each other. It was inevitable then that peer influence would create a deep impression on new Filipinas to the extent that they would invariably follow the 'advice' of the "sentors" in their relationship with their ma'am. So apprehensive were employers of the influence exerted by the "seniors" that many of them preferred to pay the extra emoluments amounting to RM20 per 'off-day' to their malds rather than allow the latter to take their bi-monthly or weekly holiday. ${ }^{41}$ 


\section{THE PRESENT-DAY SCENARIO}

The system of Filipina maid employment since its inception in Malaysla in the 1980s has lasted just over a decade. Already the Philippines government has indicated that it wants to phase out the 'export' of Filipina labour to other countries not only because of the presence of abuses in the system which have culminated in physical assaults and injury to some of its female citizens. but also because it feels that this type of migration in which the Filipina is treated as a commodity is demeaning and shameful to the nation. Migrant labour was essential and acted as a 'stop-gap' measure to help rescue a tottering economy in the 1970 s and 80 s but with economic resuscitation in the Philippines thereafter, the Filipino government has made it clear that it intends to regulate and gradually reduce the number of migrant maids overseas. The effect of such a policy can be observed from the dwindling number of Filipina maids to Malaysia in recent years; viz. from about 5000 in the late 1980s, the number has declined to approximately 2000 by the mid-1990s. ${ }^{42}$ This latter figure is expected to remain static until the end of this century not only because of government controls but also because wages of Filipina maids have increased so rapidly within the last decade that many Malaysian employers have opted for a cheaper alternative by obtaining the services of Indonesian househelp instead. ${ }^{43}$

The Malaysian government through the Ministry of Human Resources, on the other hand, has also been busy trying to streamline the structure of foreign labour inflow by standardising wage rates for Filipina as well as Indonesian migrant maids since the beginning of 1996 . Such a move is meant to curb further exploitation of employers and maids by unscrupulous employment agencies which have been overcharging them in the past. From a previous fee ranging between RM2,800 and RM3500, the Ministry has announced that the future wage rate for hiring a maid should not exceed RM2000. This sum, pegged as the ceiling fee, would cover the maid's 'airfare to Malaysia, upfront annual levy, upfront work permit, insurance for security expenses and service charges. ' 4 theck-up upon permit renewal, internal travel has been signed between the Although such a wage-structure agreement recently, the same has not yet been Malaysian and Indonesian governments a few more detalls have to been done with the Philippine government as been reported by the Malaystan prese Philippines are disgruntled with press that maid-hiring agencies in the government. Unless this fee is the low ceiling fee set by the Malaysian workers abroad in future. In the meantime, numerous contracts made between employment
agencies and prospective employers have been suspended until the issue of 


\section{TIIPINA MAIDS IN MALAYSIA IN THE $20^{\text {II }}$ CENTURY}

wages has been formally settled by the Malaysian government. This has resulted in a dearth of Filipina maids in Malaysian homes thereby causing hardship to families which have become highly dependent on services rendered by female migrant workers. Such a situation, although not reaching critical levels yet, is nevertheless bad enough to lead to maid-pinching among households or to the lllegal hiring of maids by desperate ma'am.(46) The dependence by Malaysians on foreign migrant labour only goes to show that despite her foibles and shortcomings, the Filipina maid has become an indelible part of the Malaysian scene so long as employers find difficulty in sourcing local or other foreign househelp. The recent announcement by the Ministry of Human Resources that it would soon allow other foreign maids such as Thais and Sri Lankans to be absorbed into the mainstream of Malaysian domestic labour will go a long way to relieve tight labour situation here, thereby helping to solve the Malaysian housewife's dilemma of a maidshortage in the long run. 


\section{Notes}

1. F.Zaide. Philippine Political and Cultural History. "The Philipines Since the British Invasion". Vol.II.(Manila, 1957, (revised edition), p.83.

2. Ibid., p.272-3.

3. Ibid., p.380-1.

4. Ibid.

5. S.T.Ker. "The Southeast Asian Economic Scene: A Review" in K.S.Sandhu.(Chairman, ed. committee). Southeast Asian Affairs 1979, (SEAA, 1979).(Institute of Southeast Asian Studies, (ISEAS) Singapore, 1979). p.19.

6. Ibid.

7. Ibid.

8. Ibid., p.20.

9. F.A.Alburo. "The Region in 1984: Growth and Restraint" in Sandhu, Souheast Asian Affairs 1985, (SEAA, 1985), (ISEAS, Singapore,1985), p.22.

10. Ibid. p.24.

11. Ibid. p.26.

12. G.Lycklama, "Trade in Maids: Asian Domestic Helpers in Migration:Theory and Practice" in N.Heyzer(ed). The Trade in Domestic Helpers: Causes, Mechanisms and Consequences,(Selected Papers from the Planning Meeting on International Migration and Women,guezon City, Philippines,30Nov. - 5 Dec.1987). (Asian and Development Centre(APDC). Kuala Lumpur, 1989). p.30.

13 Ibid. p.35

14. M.L. Alcid, The Recruitment Process and Work Conditions of Filipina Domestic Helpers in Hong Kong. Singapore and Saudi Arabia" in The Trade in Domestic Helpers, p.255 and 274.

15. L.Obrien. "The Effects of Industrialisation on Women: British and Malaysian Experiences" in Kajian Malaysia: Journal of Malaysian Studies, Vol. II, No. I. (Universiti Sains Malaysia, Penang, Malaysia, 1984), p.52.

16. Ibid. p.49-50.

17. Although Chinese women immigrants were exempted initially from the quota system which limited the number of immigrants to Malaya to a few thousand annually under the Aliens Ordinance 1933 , they were however, subject to the government regulations of 1938 which had the effect of reducing the total number of immigrants to 500 yearly. - see Y.F.Chin. "Chinese Female Immigration to Malaya in the 19th and 20th Centuries" in M.A.Bakar and others (eds), Historla: Essays in commemoration of the 25th Anniversary of the Department of History, University of Malaya,(University of Malaya, Kuala Lumpur. Malaysia, 1984). p.365.Also see K. Gaw, Superior Servants: The Legendary Cantonese Amahs of the Far East, (Oxford University Press, Singapore, 1988) for a narrative of amah labour in Malaysia and Singapore.

18. C.Tharan, "Fllipina Malds in Malaysia" in The Trade in Domestic Helpers. p.274.

19. V.F.Tornea and E.P.Habana, "Women in International Labour Migration: The Philippine Expertence" in The Trade in Domestic Helpers, p.66-67.

20. Alcid, "The Recruitment Process" in The Trade in Domestic Helpers. p.258.

21. Lycklama. Trade in Malds" in The Trade in Domestic Helpers, p.45. The author mentioned that both Fllipina and Filipino workers could earn wages that were flve to six times more abroad than what they were able to obtain at
home. 

nary Survey in Occasional Paper 11. (Centre for Hongkong Studies. The Chinese University of Hong Kong. Hong Kong. 1986) p.15 in Lycklama. Trade in Maids" in The Trade in Domestic Helpers, p.43.

23. Christine. aged 23. from Bagulo, for example. was married to a truck driver who did not give her any maintenance money as the bulk of his wages was spent on drink. Despite his pleas, she decided to leave him in order to become a migrant maid in Kuala Lumpur between 1989-91. During this period. her husband was killed in a road accident in Manila. After the termination of her service contract in 1991. Christine left for home but four years later. she returned to Malaysia to work as a maid in Malacca for a second time. Personal interview with Christine in the Maid -Hiring Agency in Petaling Jaya.

24. C.Tharan, "Fllipina Maids in Malaysia" in The Trade in Domestic Helpers, p. 274. Also from data collected by the writer in a personal interview with the agent of a Maid-Hiring Agency in Petaling Jaya (PJ). Selangor in 1994..

25.. Tornea and Habana, "Women in International Migration" in The Trade in Domestic Helpers, p. 67.

26. Ibid.

27. Ibid.

28. Data collected from personal interview with a Maid-Hiring Agency in Petaling Jaya.

29. Ibid.

30. Chin, "Chinese Female Immigration to Malaya" in Historia, p.370-71. Also refer to Gaw. Superior Servants.

31. Data collected from personal interview with a Maid-Hiring Agency in PJ.

32. The terminology Malaysian dollar (MS) was altered to Malaysian ringgit (RM) in the 1980s. The standard wage of RM580 per month was agreed upon in 1995 between the Malaysian and Filipino governments. Revisions in wagescale had been on the up-trend from the late 1980's onwards:- viz. RM300 p.m, then to RM450 p.m. before it was pegged at RM500 p.m. and remained there until the end of 1994. The new salary of RM580p.m. was fixed from 1995 in response to the Filipino government's plea that the wage-rate of Fllipina maids in Malaysia should be more on par with that accorded to their counterparts in other countries of Asia such as Singapore and Hong Kong.

migrants to Malaysia were the norm, there were excephad departed to the Philippines returning to Malaysia tions with maids who had departed to thort span of time for various reafor a second stint as househelp after a short spere. an easier and more sons:- viz. the higher wages they could command himent in Malaysia and/or luxurious lifestyle after the initial period of adjustitions in their villages or difficulty in re-adapting to more difflcult living writer from personal interbarrio in the Philippines. - Data collected by the wine. Melba, Mabelle. Helen views with several Filipina maids including Christne. Melba, Mabelle, Helen and Alicia.

34. Tharan. "Fulipina Maids in Malaysia" in The Trade in Domestic Helpers. p.28 in

35. Ibld. Also data collected from personal interview with a Matd PJ.

36. Tharan, "Fllipina Maids in Malaysia" in The Trade in Domestic Helpers, p.280.

in Petaling Jaya in

3. The Befrlenders is a voluntary counselling group formed churches have their own the early 1980s whilst the Catholic and Protestant in Kuala Lumpur and other main counselling groups for Filipina worshippers in Ku.

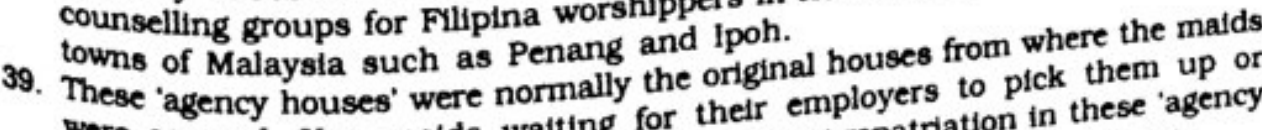
these agency malds whose contracts had expired and awating iarters of these houses. houses' were accommodated in the rooms or quart 
40. Shopping Malls in Kuala Lumpur included Sungei Wang Plaza. Bukit Bintang Plaza and Yaohan Mall as well as Subang Parade in Petaling Jaya.

41. The bi-monthly "off-days" were revised to weekly "off-days" under the amended regulations made between the Filipino Government and the Malaysian $\mathrm{Hu}$ man Resources Ministry in 1995.

42. The earlier figure of 5,000 was cited by Alcid, "The Recruitment Process" in The Trade in Domestic Helpers, p.255 while the latter figure was given as a rough estimate by the Maid-Hiring Agency in Petaling Jaya.

43. In 1995 the monthly wages of Filipina and Indonesian maids were RM500 and RM350 respectively.

44. Guoted from The Sunday Mail, 4 February 1996, p.2.

45. Ibid.

46. Personal interview with a Maid-Hiring Agency in Petaling Jaya in February 1996. 